\title{
Political Elites And The Challenges Of National Development: The Nigeria Experience
}

\author{
${ }^{1}$,Kia, Bariledum (M.Sc, Ph.D In View) ${ }^{2,}$ VURASI, SEREBE .S \\ ${ }^{1,(}$ Facilitator National Open University Of Nigeria, Port Harcourt Study Centre) \\ ${ }^{2,(}$ Mpa, M.Sc \& Ph.D In View Department Of Pol. Sci. \& Administrative Studies University Of Port Harcourt
}

Nigeria).

\begin{abstract}
Political elites and the challenges of national development: the Nigeria experience explains the country's development challenges in relations to problems associated with elite's ethnification of political process that undoubtedly affects public policy formation and implementations in Nigeria. In this case we have the syndrome of "we want our man in national politics." This practice negates meritocracy and sound developmental policy. Under this condition, national development is unattainable. To achieve national development, the government should actively encourage national integration and eschew discrimination on the ground of place of birth, tribe, religion, sex, language and political party affiliation.
\end{abstract}

\section{Introduction}

National development is a process that never transpires outside of definite social contexts. The particular strength and lapses of certain development forces and structures inherent in state formation which development actors pursue is one option but elites overriding concern have a powerful influence, if not the determining factor on the course of national development. Development has in fact been theoretically linked with elite theory since the heyday of modernization ideology when it was assumed that suitably committed elites would hopefully be agents of modernization in less developed or backward countries once they had their reckoning with traditional elites.

The leaders and most of the active supporters of the Nigerian nationalist movement came from the ranks of those who had been most strongly affected by western education influences, and in particular from the western educated, English speaking minority (Coleman, 1958). The westernized elites were crucial factors in the awakening of racial and political consciousness. Therefore, the struggle for independence in Nigeria was driven by the elites who were assumed would hopefully transform the social, economic and political sectors to ensure sustainable development.

The spread of western education presaged the appearance of the elite that eventually influence the semi-literate masses. As remarked by Macauley, "education was the progenitor of self-government". This is apt because, this class or group of people formulates national and transnational policies that enhance national development. The elites class through decision making steer other sectors of the society, hence they play greater role in national development. Thus, successful decision making, interpretation and discourse among the elite class is fundamental and crucial elements in national growth and development. In other words, power relations among the various elites reflected in the policy process in the context of the country development. However, the elite class in Nigeria seems to assumed dimension that is unusual of realistic functions in development context. Analysis of contemporary situations in Nigeria reveals that the country elite class has no consistent and significant linkage to its national exploit. The formation and conduct of Nigerian's elite group have not been translated into a source of national development, despite the fact well observed by American political scientists John Purcell(1974) that powerful initiatives from within the elite groups is critically important for national development (Frank,1991).The Nigeria elite class had little disposition to contemplate the positive use of elite advantage as strategic instrument for engineering national development. Nigeria has realized very little of her potentials because of in effective mobilization of these potentials by the elites. Today the people (masses) have limited access to education, lack of good drinking water and adequate medical care. Millions of Nigerians are said to be suffering from various deadly diseases. There is a prevalence of poor income and unemployment, street trading by children, hazardous reproductive behaviours.

The depressing picture of Nigeria is worrisome. Based on this the study consider the following questions:

[1] In Nigeria, who are the elites?

[2] On what level does elites interact in Nigeria

[3] What forum exists for this interaction?

[4] To what extent are the elite's major barriers in development process in Nigeria? 


\section{Theoretical Framework}

The framework of analysis employed in this study is political economy approach. It is important to note that there are two basic types of political economy; bourgeois political economy, and Marxist/Leninist Political economy. In a class society political economy is of a class character. Thus in capitalist society such as Nigeria, there is bourgeois political economy and proletariat (Marxist/Leninist) political economy expressing the interests of respective classes. In this study, our unit of analysis is the Marxist/Leninist political economy associated with Karl Marx's idea of Dialectical Materialism and economic determinism which according to George and Thomas in Osugwe (2008) states that societal changes and the direction of the changes are product of economic factors. It is therefore an approach to economic problems that recognizes the importance of other non-economic social facts. In other words, it enables us to take account systematically of the interactions of different elements of social life especially, economic structure, social structure, political system and the belief system of society. This affirms the fact that political economy uses other institutional variables other than economic such as politics, legal, ideology, religion, culture, etc in explaining social facts (Nnaa, 2011).

Corroborating the above fact, the radical structural theorists argued that, in understanding the causes of social problem, the Marxist Leninist approach presents a large number of such factors that make the emergence and escalation of internal crisis possible (Faleti, 2006). They contended that while economic and social factors are more common, political and institutional factors such as the structure of the state, discriminating political institutions, intergroup politics, ethnicity amongst others are critical. The main issue in this study using the Marxist political economy approach, centres on who controls the means of production, state apparatus, revenue allocation and sharing of the resources. It espouses that the ruling class, are mostly people that exercise the utmost control of power and resources.

\section{Clarification Of Concept Elite}

In this paper, the terms 'knowledge elite', 'technocrats' and 'bureaucratic elite' will be used to refer to individuals whose ability to participate legitimately in the policy process is grounded mainly on their technical and professional credentials. However, some distinctions are worth mentioning. Knowledge elites are formed by those individuals whose intervention in the policy process is based mainly on their technical credentials. They can be either inside the public sector or state apparatus (e.g., policy experts who are public servants) or outside it (e.g., consultants and academics). Technocrats are those who hold top or national political managerial positions in the public service and status apparatus (e.g., a minister and vice-minister, a Central Bank governor, the chair of a regulatory agency) as a result of their technical abilities. In this regard, a technocrat is a person who has risen to a top political position, in this case a ministerial or a national policy-decision position, as a result of his professional career path. Bureaucratic elites are those public servants who exert their technical or administrative authority to inform policy decisions through their managerial positions(e.g., permanent secretary or national director). This distinction from the overall bureaucracy is relevant in the case of Nigeria (Marcelo, 2009), which lacks a bureaucracy in the Weberian sense. Political elites are those who have decision making power in the state resulting from their statutory or institutional position, or who have influence on policy decisions as a result of their status in the ruling coalition. Moreover, in contrast to knowledge-based elites, Marc (2008) argues that, given the various attempts to define elites in the literature, it is almost impossible to come out with a general and all-encompassing definition. Rather, what would be more appropriate is to consider the elements that constitute the concept, such as inequality, predominance and organization. In Marc's words, "the first centers on a way of presenting the dichotomy of those with influence and those without, the best and the rest, or the rulers and the ruled. The latter on the other hand has a different focus, with its axis of analysis centred on forms of elite cohesion and the concentration of power'. Although ministers can be considered essentially politicians, depending on their career path, they can also be technocrats. These terms are used interchangeably because there is a potential overlap between these definitions. For example, public servants with expertise in some policy areas and who consequently inform policy decisions can also be considered elite inside the bureaucracy.

Technocrats provide a "knowledge input" to the policy process by participating at the policy design level (in their sector) and also a "political input" by participating in the decision-making level, for example, in the cabinet, influencing other decision-makers and also taking positions on policy issues. From the above elites as used here refer to political leaders at the national, state and federal levels.

\section{Historical Perspective Of Elite Formation In Nigeria}

In pre colonial Nigeria societies the elite's class were traditional rulers, prince and chiefs, wealthy long distance traders and priests. These traditional elites include King Kosoko of Lagos, King Jaja of Opobo,the Awujale of Ijebu, Oba Ovonramwen, Attahiru 11 of Sokoto Caliphate etc.However, with the development of western education, a new class, the westernised elite men and women emerged. They include Herbert Macauley, Messrs Ernest Ikoli, Samuel Akinsanya,H. O Davies, JC Vaughan, Dr. Nnamdi Azikiwe, 
Chief ObafemiAwolowo, Ahmadu Bello etc. These elites united in their struggle against colonialists. However, latter development shows that they merely united because they had common enemy the British. As soon as the European left, this unity collapsed. Each leading nationalists wanted to achieve power using the people of his tribe as the base. This shows that what was taken as unity of purpose by Nigeria nationalist's elites was only an illusion.

Fundamentally, all government have elites at the head. Everywhere elites are viewed as essential elements of the political and social life of the country and in every country ,the stability of the nation and its regime seem to depend in a large measure on way in which the elites is organized and fits with the other sectors. There are qualities which constitute the hallmark of competent groups. These qualities are so essential for national development. Essentially, elite' formation is legitimated by their identification with the most pervasive goals in society. That is, elites are an embodiment of national consensus. Elite therefore is a nexus of need fulfilment that binds situational demands and group membership. Thus, the failure and success of national development depends on elite's effectiveness in knitting together political influence so that it responds to functional demand on the system. By personalizing the national values and giving a relentless drive to development, the elite' energies the productive capacity of his society. Indeed, the quality of a nation's elites and the image which they projects upon the world constitutes an important source of power. As Stoessinger said:

No amount of manpower or industrial or military potential will make a nation powerful unless its elites use their resources with maximum effect. China and America development status is a function of their elites cohesion on national development exploit.

It is sad that Nigeria has never been lucky enough because Nigeria elites toe ethnic ties with absence of a coherent system of choice in politics and economics. This prevented the emergence of leaders who will take the country as a whole, as their constituency. Nigeria is paraded with elites that regard themselves as the canonical representative of their personal and ethnic interests. Today elites organize their kinsmen to make various demands on the State. Rather than coming together to transform the nation economically, elites mobilise their tribal forces under sub national organisations to threaten national survival.

\section{Nigerian's Elites And National Development Experience.}

According to Tamuno cited in Obaro 1980, prior to British colonization, what is today known as Nigeria had various ethnic cultural communities with varying forms of state formation process. The various ethnic groups were joined together in 1914 through the Lord Lugard project and ruled as imperial state. The imperial state was organized and consolidated through ethnic based policy of regionalism, a political formation that post colonial Nigeria elites found difficult to depart from it. Today politics of ethnicity or region has become the ideology creating and sustaining power structure among the elites in Nigeria. People are now made to treat ethnicity or region as relevant to their personal and collective choice of candidate during election. This ethnic or regional dynamic is further reinforced by the relative economics prosperity associated with real or imagine favour derived from political advantage that accrue to group or region in control of public affairs in Nigeria the elites overriding concern is to preserve the postcolonial status quo with themselves in its commanding positions. The masses that had been mobilized and politicized on behalf of a universal goal now had to be depoliticized rapidly in the service of elite domination. Because ethnicity is close to core of individual identity, ethnic movements is created and use by the elites in furtherance of their own special interests which are time and again constitutive interests of the emerging social classes. In this way, ethnicity becomes a mask for class privileges (Sklar 1967). The dominant classes unable intrinsically to increase production because of their dependent nature on the capitalist relation of production, this class depend on the state device to increase their benefits from the society.

Part of the ethnic scheme is seen to be part of 'the mechanism through which the political elite maintain power and exercises influences. It is the attribute of elite behavior... the educated elite become the chief proponents and purveyors of parochialism' (Dudley 1973)Mamdani (2002)noted that the transference of cultural identities to the political domain by the political elites was to hijack power by using identity as a basis for condemnation, discrimination and marginalization. Such segregation along ethnic division is employed to discriminate not because of the superiority of a particular ethnic group over another but in competition to control the economic spoil of the nation - state. In 1949, Azikiwe Shows his ethnic bias when he remarked: It would appear that the God of Africa has specially created the Ibo nation to lead children of Africa from the bondage of the ages...the martial prowess of the Ibo nation at all stages of human history has enabled them not only to conquer others but also to adapt themselves to the role of preserver. The Igbo nation cannot shirk from its responsibility (Nnoli 1978).The NPC equally made such sentimental remark; It is the southerner who have power in the North. They have control of the railway stations, of the Post Offices, of Government Hospitals, of the Canteens; the majority employed in the Kaduna secretariat and in Public Works Department are all southerners; in all the different Departments of Government it is the Southerner who has power (Coleman 
1958:)With intensive competition among Nigerian elites for control of the spoils of office, politics become a winner-takes-all affair. The political parties in control in each region easily became weapons in the hands of major nationality groups for the continued marginalization of the minorities. Oppressed minorities began seeking solace in the opposition parties with inevitable consequences of politicization of ethnicity. The expulsion of Eyolta, a minority Efik, from the Igbo dominated National Council of Nigerian Citizen (NCNC)led by Nnamdi Azikiwe in 1952 resulted in Eastern Region minorities forming the rival National independent Party, with EyoIta as president (Ojo and Fawole2004).

The implementation of the Macpherson constitution of1951 accelerated the drift towards sub-group national ism and tribalism. Educated Nigerians who aspire to fill new position of power and status opened up to Nigerians by that constitution realized that their most secure base of support would be the people of their own groups. The indirect electoral system strengthened this realization.Manipulation and exploitation of ethnicity became a veritable tool of political contest. Thus, a symbiotic relationship develops between politicians who wish to achieve their own positions, and their 'people', who fear political domination and economic exploitation by a culturally distinct group allegedly organized for themselves. A politician thus gains a tribal power by successfully manipulating the appropriate cultural symbols and by articulating and advancing his peoples collective and individual aspiration (which he himself probably helped to arouse) (Graft 1983).

With a weak economic base, Nigerian elite was rendered incapable of fulfilling the historical role played by its European counterpart i.e. the development of the forces of production. The dominant class at political independence was a pathetic parody of what a dominant class is (Ihonvbere 2001). They were merely recipient of a socio-economic system and state structure created by and for the metropolitan power. The elite seize control of the centre to redeploy it rather than transform it. They were unable to subordinate the relatively high developed state apparatus. According to Alavin (1972) the relatively autonomous role of the state apparatus allows the neo-colonialist bourgeoisies pursue their class interesting the post-colonial societies. Loss of political legitimacy is a crucial indication of state failure and collapse (Murunga2004). The incidents of vested interests and crisis of legitimating have been attributed to the configuration of the dynamics of social class. Ninalowo(1999) argues that for society not to be propelled toward self-annihilation through intra-class and inter class struggle over mutually contradictory vested interests, it become historically incumbent on the state to bring about orderliness via the abiding interests of legitimation. Habermas (1986) points out "the acquisition of legitimacy (through manipulation) is self-destructive as soon as the mode of acquisition is exposed. Although coercion is the ultimate basis of power, it is not a sufficient basis of governance. While force and manipulation can sustain a government, voluntary acceptance is more enduring, stable and reliable basis of governance (Osaghae,Isumonah and Albert 1998. Legitimacy crisis occurs when citizenship rights and benefits are largely denied, and the states seems out of reach, sub-national identities then form basic source of support and the individual may constitute a platform of résistance against the state. In this context, transformation of ethnic groups from group in them to group for themselves is more likely (Adejumo 2001). In a situation of loss of legitimacy, the state loses the willing allegiance and legitimizing support of its population giving way to alternative centre of power within the territorial space of the nation - state. A discrepancy in invested interest of the elites and general interest and value deepens the crisis of legitimacy. Ninalowo (1999) purports the ultimate test of the legitimation resides in people's fulfilment of their needs, aspirations, value and interest. Widening disparities in access and opportunities, socioeconomic insecurity, corruption, politics of exclusion of the vast majority of the

populace from the state and increasing enrichment of the few, politicization of ethnicity has led to loss of confidence among many Nigerians in the Nigerian state. Babawale (2006) writes 'the level of pillage that goes on within the state apparatus is reflective of the elites' loss of confidence in the Nigerian project'. Similarly, Ihonvbere (2001) adds without avenue of legitimacy, the government is de-linked from the society and alienated from it. This makes mobilization of the society for development impossible; the parasitic elite preoccupation is primitive accumulation and not welfare and satisfaction of the governed (Onuoha, 1999).Exploitative elite that did not meet the aspirations or expectations of the people give rise to legitimacy crisis. Such unproductive elites whip up ethnic sentiments and emotions to enhance their strategic positions in the Scheme of things. According to a Northern politician 'we had to teach the people to hate southerners; to look on them as people depriving them of their rights, in order to Win them over" (Theen and Wilson 2001). Politics in Nigeria is conceptualized by various factions of the elites as a competition for crude accumulation for personal Wealth but it portrayed as a mean of enhancing ethnic interest. Thus political competition has fuelled ethnic Conflicts, instability and violence (Ojo and Fawole2004).Politics among the ethnic-based parties in the post-Independence years was dominated by competition for hegemony among the dominant ruling class. According to Theen and Wilson (2001) since the parties were closely tied to particular ethnic groups, their electoral Strategies focused not so much on broadening their base to include new social categories but rather on how to mobilize the seemingly fixed group of supporters in order to maximize turn out. The ethnic elements in elite's formation in Nigeria have implications for the balance of power that shapes policy choices and 
implementation, as well as its results. Hence: a) how elites emerge or consolidate their roles as part of the policy process; b) what the elites' strategic interests are; and c) how the relationship between knowledge elites and political elites shapes policy choices and implementation in the context of pursuance of the development agenda. This make their roles in the policy process more apparent than real. Building a developmental state in a country where national issues are giving ethnic interpretation is challenging.

The ethnic power relations involved in the policy process, the absent of elites that contribute to a positive political transformation make decision-making and the implementation of policies in Nigeria complex, chaotic, uncertain, unpredictable, and sometimes, solutions not always being aligned with national realities as the main actors - bureaucrats and politicians are concerned either with the ethnic interest or with their own parochial interests (Lane, 2000]. In this concept, policy-making is an incremental process in which adjustments are continuously made to deal with development problems related to complexity, uncertainty and ignorance about the major issues influencing the trajectory of the development process.. It is essential to argue that in Nigeria the possibility of the policy process being high-jacked by particular groups and used to respond to their clienteles through relations of patronage is clear. Therefore, development problems in Nigeria centre around the elites abuse of development policy process, which comprises a set of four elements, namely 1) the constitution of power - the way power is made up as a result of the underlying socio-economic structures in Nigeria 2) the distribution of power - while power is formed in response to social changes, it is not distributed in response to challenges that require 'freezing' relations in order to obtain greater certainty and predictability; 3) the exercise of power - what means are used in exercising power; and 4) control of power - the extent to which power is checked and the various ways in which people constrain the use of power, which can range from coercion to persuasion. The ethnic feat of elites in Nigeria affect agenda setting - the general policy framework or strategy that a country relies upon; 2) policy formulation - the formulation of specific policies at the national level; 3) policy implementation - activities associated with putting policies in place; and 4) policy effects -the effectiveness (what has been achieved) and legitimacy (how it has been achieved), which implies analysing how the country's citizens relate to the government and other public institutions (Hyden, 2006). The policy process is a combination of political and technical aspects .However; in Nigeria the relationship between the actors involved takes different forms as ethnic politics abuse public administration to the extent that there is no clear separation between politics and public administration. This has clear implications for the role and behaviour of elites in the policy process. In this regard, Nigeria lacks the Weberian perspective (Weber, 1982) bureaucracy elites one that pursues its collective interests through the discharge of its authority in a legalrational and impersonal fashion, in stark contrast to the patrimonial form of organization that mainly characterized Nigeria structures. Nigeria bureaucratic elites are mere agents of politicians that end up pursuing their own interests. This has affected national development effort. The concept development here mean process that raise a nation's standard of living, to free its population from a life of subsistence agriculture to improve health and health care, and to effectively join a world commercial community. It mean that people are the real wealth of a nation and the expansion of

people's freedoms to live long healthy and creative to advance other goals .Thus ,national development is one that put people first and enhance their empowerment ,creation of favourable social and political environment for equal participation in decision making process.

\section{Conclusion And Recommendations}

Nigeria today wallow in the blind alley of development . This is one fact that stirs no controversy . The possible area of controversy, however, may relate to the explanation of this situation .However, the discussion of the study has shown that the elites roles in national development is numbed, trapped, and caged by ethnicity. This is obviously correct because history has shown that the success and failure of any nation or people is largely a reflection of its elites approach to national development .Nation that developed owe such status to dynamic and resourceful elites who had vision of how their country not tribe, religion should be in the comity of nation and then determine the path of strategy to achieve the define goals. Developmental states are usually characterized by a leadership which is strongly committed to developmental goals and which places national development ahead of personal enrichment and/or short-term political gains. The success of Asian Tigers appears to rest on successful elite cohesion. The elites group function actively in terms of national development .In these countries, internalized elites cohesion contributed greatly to national development. The elites consciously risk political gain to achieve sound economic development. A good development policy is linked with regime survival and sound economic policy is considered good politics. Therefore, to produce a positive economic transformation leading to development, the dynamics of the policy process between elites must be designed to overcome ethnic politics to a degree of political stability to sustain national development efforts in Nigeria.

I. There should be a fundamental restructuring of the Nigerian state through the "recurring decimal" of national conference. 
II. Devolution of power to the component groups on the basis of ethnic nationalities in the true spirit of federalism. This will help to reduce the source of tension and terrorism, and also the struggle for state power among the various ethnic groups.

III. The monopoly of power by few ruling class should be broken. Political power holding should not be vested with just few ruling elites, rather it should be re-distributed to accommodate all groups or constituents of the Nigerian state.

IV. Government should embark on development projects and programmes that are of priority to the people in the Muslim dominated region of the north as well as other parts of the country with the aim of winning over the locals who are easily recruited into terrorist (vanguard) groups. And the project should be such that generate meaningful employment for the vulnerable youths.

V. The monstrous evil of corruption by political office holders should be viewed as a crime that attracts stiffer punishment.

\section{References}

Adejumobi S (1996). Citizenship, rights, and the problem of conflicts and civil wars in Africa, Human Rights Quarterly vol. 23. Alavin H (1972). The state in post-colonial societies: Parkistans and Bangladash. New left Review, No. 74.

[3] Babawale T (2006). Nigerian in the crises of governance and development a retrospective and prospective analysis of selected issues and events. The political economy of development, governance and globalization, Lagos: Political and Administrative Resources Center (PARC).

[4] Coleman JS (1987). Nigeria background to nationalism, Berkeley and Los Angeles: University of California press.

[5] Dudley L (1973). Instability and political order: politics and crises in Nigeria, Ibadan: University of Ibadan press.

[6] Frank, I (1991). 'American Think Tanks: Policy Elites and the Politicization of Expertise'. Governance: An International Journal of Policy and Administration Vol. 4, nº 3, July 1991. Pp. 332-353.

[7] Graft W (1983). African elites theories and Nigeria elites consolidation: A political economy analysis in Y Barongo (ed) political science in Africa. A critical review, London: Zed press Ltd.

[8] Habermas J (1986). Legitimation crisis. RC Macridis and BE Broun (eds) Comparative politics: Notes and Readings, Chicago: The Dorsey press.

[9] Hyden, G (2006). 'Beyond Governance: Bringing Power into Policy Analysis'. Forum for Development Studies, Working Paper No. $2010 / 05$.

[10] Ihonvobere J (2001). Dismantling the leviathain: constitutionalism and the national question in Nigeria.12th Convocation Lecture of the Lagos State University.

[11] Lane,J(2000). The public sector: concept, models and approaches. London: Sage.

[12] Mamdani M (2004). Making sense of political violence in postcolonial Africa, Identify Culture and politis, 5(1,2):9-20.

[13] Marc,S (2008).n 'Inside the Autonomous State: Programmatic Elites in the Reform of French Health Policy'. Governance:An International Journal of Policy, Administration, and Institutions, Vol. 21, No. 1,

[14] Marcelo, M (2010). 'Mozambique's Elite: Finding its Way in Globalized World and Returning to Old Development Models at www.info.com

[15] Marcelo M (2009). 'Is Mozambique's elite movingfrom corruption to development?'UNU-WIDER Conference on the Roleof Elites in Economic Development, Helsinki, Finland, 12-13 June 2009

[16] Ninalowo A (1999). Theoretical underpinnings in A Ninalowo (ed.) Crisis of legitimation pp1-16.

[17] Nonli O (1978). Ethnic politics in Nigeria, Enugu: Fourth dimension publishers.

[18] Ojo O and Fawole N (2004). Ethnic relation and politics in Nigeria.LegonJournalof International Affairs, (1):142-159.

[19] Onuoha B (1999). Political power blocs and legitimationcrisis.In A.

[20] Osaghae E (1992). Ethnicity and democracy. In AFasoro et al (eds.) Understanding democracy, Ibadan: Book craft ltd.

[21] Sklar R (1967). Political science and political integration, Journal of modern African studies, Vol.v, No 1, pp6-8.

[22] Theen RW and Wilson FL (2001). Comparative politics an introduction to seven countries fourth dimension, London: Prentice hall international (UK) ltd. 